\title{
Ideja pedagoške deontologije utemeljena na konceptima dužnosti
}

Mirko Lukaš**

mirkolukas64@gmail.com

https://orcid.org/0000-0003-2725-3035

Dean Cikovac ${ }^{* * *}$

dcikovac@ffos.hr

https://orcid.org/0000-0002-9560-1970 https://doi.org/10.31192/np.19.2.11

UDK: 37:171

171:37

Pregledni članak / Review Primljeno: 5. prosinca 2020. Prihvaćeno: 26. veljače 2021.

Rad donosi mogućnosti utemeljenja pedagoške deontologije razmatrajući tri različita filozofska koncepta putem kojih se etičkim diskursom odgojno-obrazovnoj djelatnosti naglašava trajna potreba moralnog odgojnog djelovanja. Navedenim stajalištem ukazuje se na snažnu potrebu aktualiziranja, njegovanja $i$ razvijanja moralne svijesti odgojno-obrazovnih djelatnika koja se u odgojnom procesu posreduje odgajaniku kao moralna spoznaja i iskustvo. Deontološki pristup u pedagoškoj djelatnosti uključuje posjedovanje i poštovanje profesionalne dužnosti odgojitelja u odnosima prema odgajaniku, ostalim čimbenicima odgojne djelatnosti i prema cjelokupnoj profesiji. Rad prezentira tri različita filozofska koncepta ideje dužnosti predstavljena u radovima Marka Tulija Cicerona, Immanuela Kanta i Jeremyja Benthama. Analizom autorovih promatranja $i$ odrednica ideje dužnosti mogu se odrediti smjernice za suvremeni pristup poželjnog moralnog odgojnog djelovanja. Rad ideju dužnosti promatra kao obvezu, odgovornost $i$ svijest odgojno-obrazovnih djelatnika koji svojim postupcima i izjavama djeluju na cjelovit razvitak osobnosti odgajanika. Stoga odgojno-obrazovni proces uz razvitak nužno mora djelovati i na zaštiti odgajanika od mogućih štetnih utjecaja koji se svakodnevno pojavljuju kao moralno upitni i odgojno neprihvatljivi.

Ključne riječi: deontologija, dužnost, moral, odgojitelj, profesija.

\footnotetext{
* Izv. prof. dr. sc. Mirko Lukaš, Sveučilište Josipa Jurja Strossmayera u Osijek, Filozofski fakultet, Lorenza Jägera 9, HR-31000 Osijek.

*** Dean Cikovac, mag. educ. fil. i pedag., Gimnazija Gaudeamus, Školska ulica 6, HR-31000 Osijek.
} 


\section{Uvod}

Deontologija pedagoške profesije, kao posebna grana etike, koncentrira se na specifične dužnosti koje proizlaze iz načela kojih se u normativnom pogledu svaki odgojitelj treba pridržavati u svom profesionalnom radu. ${ }^{1}$ Ideju deontološkog određenja pedagoške djelatnosti čini normativni pristup putem kojeg se nastoji zajamčiti objektivnost i profesionalizam. »Pedagoška profesija posebno predstavlja istaknuti etički i deontološki zahtjev u osobnom i profesionalnom razvoju odgojno-obrazovnih djelatnika. « ${ }^{2} \mathrm{U}$ tom smislu je odgojno-obrazovni čin nužno određen uključenošću osobnosti odgojitelja ${ }^{3}$ kojom on neposredno utječe na razvoj i odvijanje odgojno-obrazovanog procesa. Stoga pedagoška deontologija naglašava potrebu razvoja deontološke svijesti odgojitelja za postizanjem usmjerenog odgojno-obrazovnog djelovanja kojim će se zaštititi i očuvati mentalno i tjelesno zdravlje, integritet, ali i sposobnost kritičke procjene kako vlastitog tako i tuđeg ponašanja od strane odgajanika. ${ }^{4}$

Djelokrug odgojitelja uključuje društvenu, a time i moralnu djelatnost koja se odvija bez obzira na razvijenost njihove moralne svijesti u obliku djelovanja, promišljanja ili ponašanja. »Obrazovanje je moralni pojam. $\aleph^{5}$ Svako odgojnoobrazovno djelovanje se temelji na posredovanju vrijednosnog iskustva kao odgojnog koje se reflektira u razvoju moralne svijesti odgajanika.

»Odgajatelj odgojem uvijek nešto hoće i samim time je njegovo djelovanje vrijednosno određujuće za odgajanika. Ono bi to bilo čak i onda kada to odgojitelj ne bi htio, tj. kada bi to pokušao izbjeći. Odgoj ne mora uvijek imati istu svrhu, ali svrhu uvijek mora imati. Vrijednosti kojima je kao djelatnost nošen mogu biti različite, ali su u njemu uvijek prisutne. ${ }^{6}$

Premda se mnogi nastavnici u svom radu pokušavaju ograničiti samo na ulogu prenošenja podataka to je u nastavnom procesu uistinu nemoguće.? Moralna djelatnost poučavanja nošena je vrijednostima koje su posredovane mišlju, likom i djelom samog odgojitelja, a »socijalno i moralno učenje odvija u svakom slučaju - htio to nastavnik ili ne ${ }^{8}{ }^{8}$

U tom smislu etička prosudba može se razumjeti kao trajan aspekt svakodnevnog pedagoškog posla, što sugerira da cjelokupno promišljanje i djelovanje

${ }^{1}$ Usp. Mirko LUKAŠ, Marko MUŠANOVIĆ, Osnove pedagogije, Osijek, Vlastita naklada, 2020, 116-126.

${ }^{2}$ Usp. isto, 117.

${ }^{3}$ pojmom odgojitelj u ovom su radu obuhvaćeni svi ostali nazivi za djelatnike u odgoju i obrazovanju: učitelje, nastavnike i profesore, zanemareno samo u citiraju.

${ }^{4}$ Usp. Galiyabanu KERTAYEVA, Deontological Preparedness of the Teacher as a Guarantee of Psychological Comfort in the Classroom, Literacy Information and Computer Education Journal, 4 (2013) 4, 1252-1258.

5 Usp. Maja ŽITINSKI, Obrazovanje je moralni koncept, Naše more, 3-4 (2006) 53, 140-147.

${ }^{6}$ Usp. Milan POLIĆ, K filozofiji odgoja, Zagreb, Znamen, 1993, 21.

7 Usp. Ewald TERHART, Metode poučavanja i učenja, Zagreb, Educa, 2001, 173.

${ }^{8}$ Usp. isto, 171. 
odgojitelja ima neizbježnu etičku dimenziju. ${ }^{9} \mathrm{U}$ tom pogledu odgojno-obrazovni proces nije dostatno promatrati uzimajući u obzir samo njegovu obrazovnu komponentu, već se čak i važnijom smatra ona odgojna. Locke će u tom pogledu naglasiti da je dobar i moralan ljudski karakter koji odlikuje razvoj moralnih vrlina u mnogim aspektima važniji od akademskog znanja i intelektualnih sposobnosti pojedinca. »Vrlinu je teže dobiti od znanja o svijetu; i ako se izgubi u mladiću, rijetko se oporavi. «10

Suvremena odgojno-obrazovna praksa preferira izobrazbu vještina te ostvarivanje ishoda učenja u obliku kompetencija, dok je odgojna i ona pod kojom se podrazumijeva razvoj moralne svijesti arbitrarna, neodređena i zapostavljena. Tome u prilog idu rezultati ispitivanja stavova studenata nastavničkih zanimanja o moralnoj djelatnosti poučavanja koji pokazuju da budući nastavnici iznose svoje dvojbene stavove o pitanju odgovornosti za odgojnu ulogu škole. U njihovim odgovorima prevladava stav da oni imaju tek sekundarnu i manje bitnu ulogu u odgoju pa time i u formiranju moralnog karaktera učenika. ${ }^{11}$ Jača odgojno-obrazovna tendencija u kojoj »škola bilježi nedostatak učinkovitosti po pitanju prijenosa znanja o čovjeku i vrijednostima ${ }^{12}{ }^{12}$

Ključnim postaje pitanje: Žele li se odgojno-obrazovni djelatnici istinski posvetiti promišljanju aspekta moralnog odgoja u okviru poučavanja ili ga naprosto ignorirati? U kojem god pravcu bila usmjerena njihova odluka, ona ih ne oslobađa moralne dužnosti u razumijevanju načina na koji vrijednosti dopiru u škole i ne omogućuje im izbjegavanje fundamentalne moralne svrhe odgoja i obrazovanja. ${ }^{13}$ Budući da je moralni odgoj u školama neizbježan, nastavnici imaju posebnu odgovornost i obvezu da ovu determiniranost ne ignoriraju, jer time otvaraju prostor opasnostima u kojima moralni odgoj može postati zanemarivan ili potpuno loš. ${ }^{14}$

Pedagoška deontologija upravo u tom smislu nastoji objediniti i u normativnom pogledu determinirati odgojni aspekt pedagoške djelatnosti. Vođena idejom dužnosti, utemeljena je na svijesti o učincima vrijednosno angažiranog procesa, a to sâm odgojni čin jest. ${ }^{15} \mathrm{U}$ tom smislu se učinak odgojnog djelovanja ne prepušta arbitrarnoj, subjektivnoj i proizvoljnoj odluci odgojno-obrazovnog

${ }^{9}$ Usp. Jukka HUSU, Real-world Pedagogical Ethics. Mission impossible, Teacher Development, 2 (2003) 7, 311-326.

${ }^{10}$ Usp. John LOCKE, Some Thoughts Concerning Education, Boston, Gray \& Bowen, 1830, 86.

${ }^{11}$ Usp. Matthew N. SANGER, Richard D. OSGUTHORPE, Teacher candidate beliefs about moral work of teaching, u: Matthew N. SANGER, Richard D. OSGUTHORPE (ur.), The moral work of teaching and teacher education, New York, Teachers College press, 2013, 14-25.

${ }^{12}$ Usp. Raymond BOUDON i Lise MINGASSON, Entre valeurs de l'espace privé et valeurs communes - Une articulation complexe, Informations sociales, 8 (2006) 136, 26-34, 27.

${ }^{13}$ Usp. Darcia NARVAEZ, Daniel K. LAPSLEY, Teaching moral character. Two alternatives for teacher education, Teacher Educator, 2 (2008) 43, 156-172; Pat MAHONY, Should 'ought' be taught?, Teaching and Teacher Education, 7 (2009) 25, 983-989, 985.

${ }^{14}$ Usp. Lukaš, Mušanović, Osnove pedagogije..., 125.

${ }^{15}$ Usp. Ante VUKASOVIĆ, Odgojne vrijednosti i putokazi J. A. Komenskog za treće tisućljeće, Obnovljeni život - časopis za filozofiju i religijske znanosti, 58 (2003) 1, 87-98, 92. 
djelatnika, već se on temelji na svjesnoj, planiranoj, promišljenoj i odgojno usmjerenoj aktivnosti kojom se posreduju moralna i etička znanja odgojitelja čiji se učinci reflektiraju na oblikovanje moralne svijesti odgajanika. Srž moralne svijesti tako se pojavljuje kao osjećaj odgovornosti, odnosno slobode povezane sa zamišljenim ili ostvarenim činom. ${ }^{16}$

U pedagoškoj deontologiji svijest i odgovornost su usko povezani s idejom dužnosti koju čini upućivanje odgojitelja na poželjne oblike odgojnog djelovanja koji proizlaze iz osjećaja dužnosti prema odgajanicima, drugim kolegama, a u širem smislu i cjelokupnom društvu. Svijest odgojitelja o učincima njegova djelovanja mora biti utemeljena na etičkim i moralnim spoznajama jer je tek putem ovih znanja moguće djelovati na oblikovanje svijesti odgajanika. U tom smislu se posredovanje ideja moralnog djelovanja odvija kao svjestan proces koji je dio učenja, ali i navikavanja.

»Pored znanja, nečije se pozivanje na moralnu istinu mora temeljiti i na osjećaju dužnosti, jer se djela koja su istinski prosuđena kao moralno dobra, doživljavaju i kao ono što bi trebalo učiniti. Kad se ona više puta vježbaju u procesu života, razvijaju se obrasci djelovanja. «17

Stoga je deontološki aspekt pedagoške profesije posebno važno područje kojim se obrasci djelovanja u svojstvu odgojno-obrazovnih djelatnika ne odnose samo na njihov osobni i individualni životni aspekt moralnog prosuđivanja i djelovanja, već se ujedno prenose na učenike koji ih promišljaju, usvajaju i primjenjuju kao referentne modele moralnog prosuđivanja i djelovanja u osobnom životu.

\section{Odrednice profesionalnih pedagoških dužnosti}

Ideja dužnosti je bit deontološke etike kao teorije morala. ${ }^{18}$ Kantov deontološki koncept moralnosti proizlazi iz autonomije subjekta koji sebi postavlja principe iz kojih u obliku dužnosti proizlaze obveze usmjeravanja moralnog djelovanja. Tendencija objektivizacije subjektivnog principa moralnog djelovanja koju Kant naziva maksimom, određena je zakonom uma koji ima objektivnu, a time i subjektivnu vrijednost. »Radi samo prema onoj maksimi, za koju ujedno možeš htjeti da postane općim zakonom. ${ }^{19}$ Profesionalne dužnosti temelje se na prokušanim iskustvima koje definiraju strukovne organizacije u okviru profesionalne etike, a one utvrđuju niz komponenti kojih su se djelatni-

\footnotetext{
${ }^{16}$ Usp. Louis LEGRAND, Moralna izobrazba danas. Ima li to smisla?, Zagreb, Educa, 1995, 17.

${ }^{17}$ Usp. George F. McLEAN, The person and moral growth. The Dynamic Interaction of Values and Virtues, u: Luis UGALDE, Nicholas BARROS, George F. McLEAN (ur.), Love as the Horizon of Moral Education and Character Development. A Latin American Contribution for the $21^{\text {st }}$ Century, Cultural heritage and contemporary change, V/4, 1998, 191-206, 191.

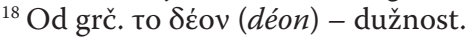

${ }^{19}$ Usp. Immanuel KANT, Osnivanje metafizike ćudoređa, Zagreb, Feniks, 2003, 183.
} 
ci dužni pridržavati u obavljanju svojih profesija. Neizostavno su to: poštenje, integritet, objektivnost na svim razinama u području djelovanja, odgovornost, povjerljivost, transparentnost, uzajamno poštovanje i poštivanje zakona kao ključni koncept. ${ }^{20}$ Pretpostavka za autonomno moralno djelovanje je razvijena moralna svijest i snaga uma za njegovo usmjeravanje. Nužnost uspostavljanja dužnosti u heteronomnom pogledu je u njenom nedostatku i razvojnoj potrebi. Zato profesionalne dužnosti ne mogu pretpostaviti autonomiju subjekta, već prvenstveno moraju skrbiti o njegovu razvoju i oblikovanju. Kant tvrdi da je čovjek kao biće obdareno umom (animal rationabile) i ima sposobnost od sebe stvoriti umnu životinju (animal rationale), ali je to predmet njegova vlastita usavršavanja, vježbe i odgoja, a ne apriorne sposobnosti. ${ }^{21}$ Stoga je i dužnosti u pedagoškoj profesiji potrebno oblikovati putem moralnih načela da bi djelovala putem zakona, principa i pravila. Unutar navedenih zakonodavnih oblika norme postaju regulacijski standardi i razvijaju se putem perpetualne dinamike u odnosima autonomnog i heteronomnog moralnog djelovanja. Razvojni stupanj moralne svijesti pojedinca uvjetuje njihovu dominaciju, a njihova funkcija postaje posredovana moralnim odgojem. ${ }^{22}$

U pogledu nastavničke profesije dužnosti se ističu kao moralne obveze učitelja prema učenicima, kao osobama koje o njima ovise, zatim drugim učiteljima i roditeljima. ${ }^{23}$ Dužnost u profesionalnom pogledu jest moralna obaveza djelatnika da svoj posao obavlja savjesno, koncizno i predano. Savjest je u tom smislu povezana s pojmom svijesti koja implicira moralnu odgovornost. Moralnu odgovornost u smislu dužnosti odgojitelja moguće je promatrati kroz principe kojih se oni moraju pridržavati u svom radu ako žele biti etični, a oni su: disciplinarna kompetentnost, efektivno poučavanje, pružanje uravnoteženog sadržaja i poticanje kritičkog mišljenja, poštovanje učenika, poštovanje akademskog integriteta i poticanje iskrenosti, objektivnost i pravednost u vrednovanju, zaštita povjerljivih informacija i primjeren odnos prema učenicima. ${ }^{24}$

U tom pogledu odgojitelj je dužan pridržavati se niza principa nastojeći pomoći učeniku proširivati njegove osobne spoznaje i pružiti mu ogledni primjer za vlastito djelovanje.

"Sustav deontoloških načela i pravila profesije trebao bi, po svojoj prirodi, biti dvojake kakvoće. S jedne strane, to bi trebala biti načela i pravila primjerena uređenju same profesije, dakle načela i pravila djelovanja učiteljske profesije,

\footnotetext{
${ }^{20}$ Usp. Lukaš, Mušanović, Osnove pedagogije..., 123.

${ }^{21}$ Usp. Immanuel KANT, Antropologija u pragmatičnom pogledu, Zagreb, Naklada Breza, 2003, 197.

${ }^{22}$ Usp. Lawrence KOHLBERG, The Cognitive-Developmental Approach to Moral Education, The Phi Delta Kappan, 56 (1975) 10, 670-677.

${ }^{23}$ Usp. Vladimir ROSIĆ, Deontologija učitelja - temelj pedagoške etike, Informatologia, 2 (2011) 44, 142-149.

${ }^{24}$ Usp. William G. HILL, Dorothy D. ZINSMEISTER, Becoming an Ethical Teacher, u: William BUSKIST, Victor A. BENASSI (ur.), Effective College and University Teaching. Strategies and Tactics for the New Professoriate, Thousand Oaks, SAGE Publications, 2012, 125-134.
} 
dok bi ih, s druge strane, trebala činiti načela i pravila ćudoređa, sredine, okruženja, tradicije, kulture i sl. $^{25}$

Kao temeljna profesionalna dužnost odgojitelja ističe se uvažavanje prvog univerzalnog principa moralnog djelovanja u odgojno-obrazovnom radu. To je izbjegavanje aktivnosti ili neaktivnosti koje mogu učenicima uzrokovati odgojnu ili emocionalnu štetu. ${ }^{26}$

U tom smislu, temeljna dužnost svakog odgojitelja obvezuje na moralno djelovanje kojim se odgojno-obrazovni aspekt njegove djelatnosti reflektira kao pozitivno iskustvo odgajanika. Takvo djelovanje uključuje razvijenu moralnu svijest iz koje proizlazi odgovornost za osobne postupke čiji učinak će imati poželjan odgojni utjecaj. Povezanost moralnog i odgojnog čina jest fundamentalno jer ako djelovanje odgojitelja nije moralno, ne može biti niti odgojno prihvatljivo. Stoga deontologija pedagoške profesije takvo djelovanje ne određuje samo kao puku poželjnost, već i kao obavezu koja treba biti odgojna i moralna dužnost.

\section{Koncepti ideje dužnosti i njihove implikacije u odgojnu djelatnost}

Moralni postupci, ponašanje i prosuđivanje reflektiraju se u odgojno-obrazovnom djelovanju svakog nastavnika, a poučavanje u cjelini kao i međusobna interakcija u razredu, uvijek je moralne prirode. ${ }^{27}$ Aspekt profesionalne dužnosti učitelja stoga moralno djelovanje propisuje u obliku moralnih obveza kojih se treba pridržavati unutar odgojno-obrazovne djelatnosti. ${ }^{28}$ Premda profesionalna etika danas dužnosti prepoznaje ponajprije u okviru profesije, ideja dužnosti je u povijesnom kontinuitetu uključena u etički diskurs još od razdoblja staroga Rima. Dužnosti kao formalni principi djelovanja zastupljeni su kod Cicerona koji piše o pravilima kojima se ostvaruje dobar život u svim njegovim aspektima. Njihova konotacija pritom nije razrađena u smislu u kojem će ih kasnije unutar deontološke moralne teorije formulirati Immanuel Kant ili Jeremy Bentham, ali u izvjesnom smislu ona nagovještava da čovjek koji poznaje što je moralno, ima dužnost u skladu s time i postupati. Stoga se u sljedećim odlomcima pobliže obrazlaže ideja dužnosti predstavljanjem njezinih temeljnih odrednica u etičkim pogledima Marka Tulija Cicerona, Immanuela Kanta i Jeremyja Benthama.

\footnotetext{
${ }^{25}$ Usp. Rosić, Deontologija učitelja - temelj pedagoške etike..., 145.

${ }^{26}$ Usp. Patricia KEITH-SPIEGEL i dr., The ethics of teaching. A casebook, New Jersey, Lawrence Erlbaum, ${ }^{2} 2002$; Lukaš, Mušanović, Osnove pedagogije..., 119.

${ }^{27}$ Usp. Cary BUZZELLI, Bill JOHNSTON, Authority, power, and morality in classroom discourse, Teaching and Teacher Education, 17 (2001) 873-884, 876.

${ }^{28}$ Usp. Giorgio VESCOVI, Etica e deontologia per la scuola d'oggi, Metodički obzori, 2 (2007) 1, 81-90.
} 


\subsection{Ciceronov pojam dužnosti}

Ciceronovo djelo $O$ dužnostima (De Officiis) prvotno je zamišljeno kao poduže pismo sinu u kojem mu otac prenosi odgojne poruke i stavove. $U$ tom pogledu ono ne samo da oslikava moralni sustav čije se proučavanje reflektira na razvoj moralne svijesti, već daje i nedvojbenu poveznicu sposobnosti moralnog prosuđivanja s odgojem. ${ }^{29}$ Ciceronovo djelo ima praktičnu namjenu pružanja uvida u osnovne principe moralnih dužnosti kao i pravila osobnog vladanja. U njegovoj ideji sve dužnosti proizlaze iz dva temeljna izvora, a ona su dobro (honestum) i korist (utile). Sukob između njih je samo prividan, a Ciceron na tragu Panaetiusa zaključuje da ništa nije korisno ukoliko nije moralno ispravno, dok moralno ispravo nije $\mathrm{u}$ isto vrijeme i korisno. ${ }^{30} »$ Nema većeg prokletstva koje je ikad napalo ljudski život od doktrine onih koji su razdvojili ta dva koncepta.«11 Onog trenutka i ako dužnosti koje proizlaze bilo iz jednog ili iz drugog izvora ikada dođu u sukob, čovjek može nedvojbeno znati kojoj dati prednost.

Moralne dužnosti su definirane kao poželjni principi djelovanja i rasuđivanja, a proizlaze iz kardinalnih vrlina kao temeljnih izvora moralnog života. ${ }^{32} \mathrm{U}$ tom smislu se moralne dužnosti temelje na mudrosti, pravednosti, hrabrosti i umjerenosti. ${ }^{33}$ Svrha moralnog života je sretan i ispunjen život koji se sastoji $\mathrm{u}$ ostvarivanju uspjeha u svim njegovim aspektima. U svojim razmišljanjima Ciceron navodi i pravila kojih je poželjno pridržavati se kada želimo održavati pristojnost:

»Pristupajući bilo kojem smjeru djelovanja, moramo se čvrsto držati triju principa: prvo, da se impuls pokorava razumu; jer nema boljeg načina od ovoga da bi se osiguralo poštivanje dužnosti; drugo, da pažljivo procijenimo važnost predmeta koji želimo ostvariti, tako da ne može biti više ni manje ni brige $\mathrm{i}$ pažnje utrošeno na njega nego što slučaj zahtijeva; treće je načelo da pripazimo na umjerenost u svemu onome što je bitno za vanjski izgled i dostojanstvo gospodina. Štoviše, najbolje pravilo za osiguravanje toga je strogo poštivanje te ispravnosti o kojoj smo govorili i ne prekoračenje. Ipak, od ova tri načela, najvažnije je držati impulse podređene razumu. ${ }^{34}$

Temeljna dužnost čovjeka određuje se kao obveza da se u svom djelovanju vodi sudom razuma i ne dopusti da njime upravljaju impulsi koje možemo poistovjetiti s nagonima i strastima. Procjena važnosti predmeta koji se želi ostvariti aludira na odmjerenost u vlastitim nastojanjima, a time se ističe dužnost primjene umjerenosti u unutarnjem prosuđivanju. Treće načelo obvezuje

\footnotetext{
${ }^{29}$ Usp. Locke, Some Thoughts Concerning Education..., 224.

${ }^{30}$ Usp. Marko Tulije CICERON, De Officiis, prev. Walter Miller, London, Heinemann, 1913, 301.

${ }^{31}$ Usp. isto, 301.

${ }^{32}$ Usp. isto, 17.

${ }^{33}$ Usp. isto, 19-112.

${ }^{34}$ Usp. isto, 145.
} 
na umjerenost u izvanjskom izgledu pa su drugim i trećim načelom usklađeni i objedinjeni aspekti tjelesnog i duhovnog. U društvenim relacijama je dužnosti moguće rangirati po važnosti.

»Lako je moguće vidjeti koja dužnost ima prednost pred drugom: naša prva dužnost je prema besmrtnim bogovima; naša druga prema domovini; naša treća prema roditeljima i tako dalje, u silaznoj skali do ostalih. « ${ }^{35}$

Dužnosti se očituju i u različitim relacijama koje čovjek ostvaruje tijekom interakcija s drugima, a posebice božanstvima, dok se važnost njihova poštovanja rangira prema stupnju objektivne važnosti predmeta u odnosu prema kojem se formuliraju.

\subsection{Kantov pojam dužnosti}

Immanuel Kant etiku promatra kao znanost o dužnostima. Dužnost nije podvrgavanje prisili izvanjskog zakona već unutarnjeg. »Pojam dužnosti već je po sebi pojam nekog primoravanja (prisile) slobodnog htijenja pomoću zakona; ta prisila može biti izvanjska ili pak samoprisila. ${ }^{36}$ Čovjek je slobodno moralno biće pa se pojam dužnosti može odnositi samo na samoprisilu. U tom pogledu važan je pojam dobre volje kojim Kant putem htijenja ističe čovjekovu moć samoodređenja prema dobru radi samog dobra, a ne posljedice koja se njime namjerava postići. Budući da volja djeluje prema osjetilnim sklonostima, samo htijenje nije dostatno da bi je moralno usmjerilo, već joj je u moralnom određenju potrebna zapovijed uma. ${ }^{37}$ »Načelo dužnosti je ono što um apsolutno, dakle objektivno, zapovijeda da treba činiti.« ${ }^{38}$

Zapovijed uma formulira se kategoričkim imperativom kao najvišim načelom ćudorednog učenja, koji je ujedno i moralni zakon. Kant stoga tvrdi da je dužnost »nužnost određenog djelovanja iz poštovanja prema zakonu «. ${ }^{39} \mathrm{Iz}$ predodžbe umnog zakona proizlazi ideja dužnosti kao obveza volje da djeluje moralno čak i kada to nije predmet njenog htijenja i sklonosti. Um formulira moralni zakon djelovanja, a volja ima dužnost prema njemu se ravnati. Budući da volja odbija prisilu, razum joj nalaže moralno djelovanje imperativom: »Djeluj prema maksimi koja ujedno može vrijediti kao opći zakon. ${ }^{40}$

Kant tvrdi da čovjek nije moralno niti dobar niti loš, jer po svojoj prirodi on uopće nije moralno biće. ${ }^{41}$ On postaje moralnim bićem kada se njegov um

\footnotetext{
${ }^{35}$ Usp. isto, 165.

${ }^{36}$ Usp. Immanuel KANT, Metafizika ćudoređa, prev. Dražen Karaman, Zagreb, Matica hrvatska, 1999, 167.

${ }^{37}$ Usp. isto, 13-14.

${ }^{38}$ Usp. isto, 23.

${ }^{39}$ Usp. Immanuel KANT, Osnivanje metafizike ćudoređa, Zagreb, Feniks, 2003, 162.

${ }^{40}$ Usp. Kant, Metafizika ćudoreda..., 23.

${ }^{41}$ Usp. Immanuel KANT, The Educational theory of Immanuel Kant, prev., ur. i pred. napisao E. F. Buchner, Philadelphia, J. B. Lipincott, 1908, 210.
} 
uzdigne do ideje dužnosti i moralnog zakona. Čovjek postaje moralno biće ako se uspije oduprijeti vlastitim sklonostima koje ga vode porocima.

»Djelovanje iz dužnosti treba dakle posve isključiti utjecaj nagnuća, a s njime i svaki predmet volje, dakle za volju ne preostaje ništa, što bi je moglo odrediti, osim objektivno zakon i subjektivno čisto poštivanje toga praktičkog zakona, dakle maksima. $\aleph^{42}$

Volja, neovisno o formalnom zakonu uma, sama u sebi sadrži izvjestan osjećaj za djelovanje iz dužnosti, a on je prisutan u obliku ljudske savjesti. Kant ju opisuje kao »osjetljivost za ugodu ili neugodu, koja proizlazi iz puke svijesti o skladu ili sukobu našeg djelovanja sa zakonom dužnosti«.43 ${ }^{43}$ jelovanje iz dužnosti kao moralno djelovanje, vođeno je subjektivnim osjećajem savjesti, ali i objektivnim predodžbama moralnog zakona. Savjest sudi samostalno kao subjektivna, a ako djelovanje nije iz dužnosti javlja se kao glas koji na takvo djelovanje usmjerava i u skladu s tim stvara moralni osjećaj ugode ili neugode. Kant navodi da čovjek ima sljedeću dužnost:

»Da kulturu svoje volje uzdigne do najčišće krjeposne nastrojenosti, naime dotle da zakon postane ujedno pobuda njegovih dužnih djelovanja i da se zakonu pokorava iz dužnosti, a to unutrašnje moralno-praktično savršenstvo jest moralni osjećaj, jer ono je osjećaj učinka zakonodavne volje u samom čovjeku na moć djelovanja u skladu s njom, tako reći posebno osjetilo (sensus moralis) koje se doduše katkada zanesenjački zlorabi, kao da prethodi umu (poput Sokratova genija) ili kao da čak može bez njegova suda, ali je ipak ćudoredno savršenstvo koje se sastoji u tome da se svaka zasebna svrha koja je ujedno dužnost učini svojom vlastitom. « $^{44}$

U svojoj ideji Kant razlikuje djelovanje iz dužnosti i prema dužnosti. Djelovanje iz dužnosti je dobro samo radi sebe, a ne neke druge svrhe ili nauma koji se njime želi postići. Jedino takav oblik djelovanja možemo smatrati moralno ispravnim. Djelovanje prema dužnosti je djelovanje prema nekom objektu kao predmetu naše sklonosti, ali ne i poštovanja. Naše djelovanje se tada ostvaruje kao čin nauma koji pronalazi svrhu u njegovu ishodu (bio on predmet koristi, osobne dobrobiti, ugode itd.). »Podudarnost nekog djelovanja sa zakonom dužnosti je zakonitost (legalitas), a podudarnost maksime djelovanja sa zakonom je njegova ćudorednost (moralitas). $\aleph^{45}$

Unutar krjeposnog učenja Kant formulira svrhe koje su ujedno i dužnosti, a pod njima podrazumijeva vlastito savršenstvo i tuđe blaženstvo. Putem dužnosti samousavršavanja čovjek uzdiže vlastitu kulturu u kojoj najviše mjesto zauzima njegov razum.

\footnotetext{
${ }^{42}$ Usp. Kant, Osnivanje metafizike ćudoređa..., 162.

${ }^{43}$ Usp. isto, 185.

${ }^{44}$ Usp. Kant, Metafizika ćudoređa..., 174.

${ }^{45}$ Usp. isto, 23.
} 
»Čovjekova je dužnost: da se od sirovosti svoje naravi iz životinjstva (quoad actum) sve više uzdiže do ljudskosti koja mu jedino omogućuje da sebi postavlja svrhe; da podukom popravi svoje neznanje i ispravi svoje zablude, što mu ne savjetuje tehničko-praktični um namijenjen za njegove druge namjere (u umjetnosti), nego mu tu moralno-praktički um upravo nalaže i tu svrhu postavlja za dužnost kako bi bio dostojan ljudskosti koja u njemu prebiva.. ${ }^{46}$

Racionalnost u prosuđivanju i usmjeravanju čovjekova vlastitog djelovanja kao dužnost nalaže usavršavanje njegove prirode da bi u spekulativnom i kritičkom pristupu sebi kultivirao osobnu prirodu i uzdigao se na razinu svijesti koja je dostojna ljudskog bića. Čovjek je dužan razvijati i kultivirati svoje tjelesne moći u kojima su sadržane i njegove sklonosti te kulturu moralnosti unutar njega samog.

Budući da je čovjek biće koje po svojoj prirodi teži ostvarivanju osobne sreće, dužnost u djelovanju prema drugima podrazumijeva djelovanje usmjereno prema ostvarivanju njihova blaženstva. Dužnost treba biti težnja za blaženstvom drugih kao za svojim osobnim. ${ }^{47} \mathrm{U}$ tom pogledu do izražaja dolazi i druga Kantova formulacija kategoričkog imperativa u kojoj tvrdi da se prema drugome uvijek trebamo odnositi kao prema svrsi, a ne sredstvu za postizanje vlastitih svrha. ${ }^{48}$ Ljudskost u postupanju prema drugima nalaže djelovanje kojim se naš um obvezuje uputiti nas da činimo dobro jer činjenje dobra ima vrijednost samo po sebi. Čovjek je dužan njegovati tjelesno blagostanje unutar kojeg se dobrotvornost prakticira kao dužnost prema drugima i kao moralna dobrobit pa čak i po cijenu vlastite žrtve s nadom da će biti uzvraćena.

U odgojno-obrazovnoj teoriji dužnosti za Kanta čine veliku vrijednost. Dužnosti koje se propisuju djeci važne su jer samo navikavanjem na dužnosti, a ne sklonostima moguće je ispravno usmjeravati i voditi vlastito djelovanje u životu. Sve što podrazumijeva ideju dužnosti ujedno je povezano i s pokoravanjem razumu. ${ }^{49}$ Kant stoga smatra nužnim od rane dobi prakticirati djelovanje koje je vođeno dužnostima i njegovanjem i razvijanjem osjećaja za krjeposti. ${ }^{50}$ Budući da krjepost nije nasljedna, nego mora biti stečena, ona je na taj način već sadržana u nama. Nužno je učiti i poučavati krjepostima da bi se one razvijale i ostvarivale. ${ }^{51} \mathrm{U}$ tom nastojanju sadržane su temeljne ideje Kantovih pedagoških misli.

\footnotetext{
${ }^{46}$ Usp. isto, 174.

${ }^{47}$ Usp. isto, 175.

${ }^{48}$ Usp. Kant, Osnivanje metafizike ćudoređa..., 61.

${ }^{49}$ Usp. Kant, The Educational theory of Immanuel Kant..., 193.

${ }^{50}$ Usp. isto, 190-191.

${ }^{51}$ Usp. isto, 278.
} 


\subsection{Benthamov pojam dužnosti}

Pojam dužnosti Bentham opisuje kao činjenje onoga što je prikladno i ispravno učiniti, a to se u okviru znanosti definira kao znanje onoga što je prikladno učiniti u svakoj okolnosti. ${ }^{52}$ On pojam dužnosti razmatra usporedno s pojmom interesa tvrdeći da, bez obzira na apstrahiranje i dogmatiziranje pojma dužnosti, uvijek će on ostati podređen pojmu interesa. Stoga zaključuje da »ne može biti čovjekova dužnost činiti ono što je njegov interes ne činiti«. ${ }^{53} \mathrm{U}$ slučaju da se dužnost uvijek postavlja suprotno interesu, Bentham je mišljenja da u tom slučaju dužnost ne bi vodila sreći. Stoga tvrdi: »Vidjet će se da u općem smislu života žrtvovanje interesa zbog dužnosti nije ni izvedivo ni toliko poželjno i da, kad bi mogla, sreća čovječanstva se time ne bi promicala. ${ }^{54}$

U slučaju kada nije moguće utvrditi da je neka radnja ili način ponašanja $\mathrm{u}$ interesu čovjeka Bentham smatra uzaludnim pokušaj dokazivanja da je to njegova dužnost. Interes i dužnost ujedinjeni su u promicanju javne sreće jer ona nije ništa drugo, nego suma individualnih dijelova sreće svakog pojedinca. Sreća kao univerzalni interes i svrha moralnog djelovanja, zbog mogućih krivih procjena, osobnih interesa i štetnih posljedica, ipak ne može biti određena sasvim subjektivno. Stoga Bentham tvrdi:

»Dakle, princip na kojem se temelji deontologija je princip korisnosti; drugim riječima, svaka je akcija ispravna ili neispravna, vrijedna ili nedostojna i zaslužuje odobravanje ili neodobravanje, proporcionalno svojoj tendenciji da doprinese ili umanji količinu javne sreće. ${ }^{55}$

Korist kojom se ostvaruje najveća količina javne sreće je objektivno određeni princip moralnog djelovanja. Bentham će stoga utvrditi: »Etika se općenito može definirati kao umijeće usmjeravanja čovjekovih djela na stvaranje najveće moguće količine sreće od strane onih čiji je interes vidljiv. ${ }^{56}$ Etika je umijeće samo-upravljanja ili ovo umijeće Bentham još naziva i privatnom etikom. Budući da čovjekova sreća ovisi prije svega o dijelovima njegovog ponašanja koji su usmjereni na njegov vlastiti interes, on ima dužnost prema sebi koja se sastoji u razvijanju vlastite sreće.

»Etika se, dakle, ako je to umjetnost usmjeravanja čovjekovih postupaka u tom pogledu, može nazvati umjetnošću izvršavanja svoje dužnosti prema sebi i

\footnotetext{
${ }^{52}$ Usp. Jeremy BENTHAM, Deontology or the Science of Morality. In which the Harmony and Coincidence of Duty and Self-interest, Virtue and Felicity, Prudence and Benevolence are Explained and Exemplified, sv. 1, London, Longman i dr., 1834, 21, 36.

${ }^{53}$ Usp. isto, 11.

${ }^{54}$ Usp. isto.

${ }^{55}$ Usp. isto, 23-24.

${ }^{56}$ Usp. Jeremy BENTHAM, An Introduction to the Principles of Morals and Legislation, Kitchener, Batoche Books, 2000, 225.
} 
osobinom koju čovjek očituje izvršavanjem ove grane dužnosti (ako dužnost nekako treba nazvati) jest dužnost razboritosti. $\ll^{57}$

U drugom aspektu Bentham uviđa da čovjekov interes i sreća mogu ovisiti o dijelovima ponašanja i drugih osoba. Ako čovjekova sreća ovisi o dijelovima njegova ponašanja koja mogu utjecati na interese drugih pojedinaca o njemu, tada možemo reći da njegova sreća ovisi o njegovoj dužnosti prema drugima. Stoga Bentham tvrdi:

»Etika se onda, ako je to umjetnost usmjeravanja čovjekovih postupaka u tom pogledu, može nazvati umjetnošću izvršavanja svoje dužnosti prema bližnjemu. Sada se sreća bližnjega može konzultirati na dva načina: 1. Na negativan način, pokušavanjem njenog umanjivanja. 2. Na pozitivan način, proučavanjem njenog povećavanja. Dužnost čovjeka prema bližnjemu prema tome je djelomično negativna, a dijelom pozitivna, otpuštanje njene negativne grane je poštenje, a otpuštanje pozitivne grane je dobročinstvo. ${ }^{58}$

U svojoj ideji Bentham prepoznaje tri oblika dužnosti koji se ogledaju kao ljudske krjeposti. Prvi se oblik odnosi na čovjekovu dužnost prema sebi koji on naziva dužnost razboritosti. Drugi oblik se odnosi na dužnost prema drugima u pogledu ne nanošenja štete drugima koji se naziva dužnost poštenja. Treći oblik se odnosi na dužnost prema drugima u pogledu pomaganja drugima koji se promatra kao dužnost dobročinstva.

\section{Zaključak}

U pogledu temeljnih principa dužnosti predstavljeni deontološki koncepti su u svojoj osnovi drugačiji toliko da se u aspektima razumijevanja pojmova npr. koristi i interesa, potpuno razilaze s polazišta poimanja njihove moralne relevantnosti. Ali, ideja dužnosti postaje temelj deontološke etičke teorije i, promatra li se s pozicije Ciceronove koncepcije, ona nužno uključuje racionalno prosuđivanje moralnog djelovanja koje je po naravi objektivno. Dužnosti koje proizlaze iz koristi Ciceron podređuje onima koje proizlaze iz dobra. Bentham se, nasuprot tome, odlučuje na njihovu nužnu povezanost. Kant odbacuje bilo koji oblik empirije kao moguć princip iz kojeg proizlazi ideja dužnosti i on postavlja čistu neempirijsku formu moralnog zakona kao načelo moralnog djelovanja. U tom konceptu moralno djelovanje nije određeno učinkom, već samim motivom.

Ipak, sva tri filozofa slažu se u istoj svrsi dužnosti kao moralnog djelovanja koje se ogleda u ostvarivanju sretnog života. Promatrajući suvremeni pedagoški odgojni pristup uočavaju se nužnosti i potrebe osvješćivanja ideje dužnosti u

\footnotetext{
${ }^{57}$ Usp. isto, 226.

${ }^{58}$ Usp. isto.
} 
procesu odgojno-obrazovne zbilje vodeći se objektivnim principima moralnog djelovanja utemeljenim na razumskoj refleksiji. Ciceron, poput Kanta, smatra da dužnost usmjerava čovjeka da se u svom djelovanju vodi sudom razuma i ne dopusti da njime upravljaju nagoni i strasti, dok Bentham kao dužnost prema sebi i drugima, a kada je uključen njihov interes o njemu, isto tako važnim smatra razvoj krjeposti razboritosti.

Ideja pedagoške deontologije vodeći se smjernicama unutar analiziranih koncepata dužnosti implementira u svoj predmet sljedeće spoznaje. Ciceronova odrednica dužnosti proizlazi iz kardinalnih vrlina i usvaja se u pogledu potrebe razvoja i njegovanja vrlina odgojitelja čija se neposredna uključenost u odgojnoobrazovni proces reflektira na moralni razvoj odgajanika. Kantova odrednica dužnosti proizlazi iz autonomije subjekta i implementira se u pogledu nužnog samorazvoja i stalnog usavršavanja refleksivnih moći odgojitelja za ispravno moralno prosuđivanje i djelovanje. Moralno i odgojno djelovanje se prikazuju u smislu njihove nedvojbene i nedjeljive povezanosti. Razvijena moralna svijest se u odgojnom procesu nužno reflektira u postupcima koji imaju posljedice na uspjeh u cjelovitom odgojnom radu. Odgojitelj vođen idejom dužnosti djeluje objektivno i primjenjuje osobne moralne spoznaje, kako u kritičkom promišljanju vlastitih postupaka (što uključuje dužnost prema sebi) tako i u interakciji prema drugima (što uključuje dužnosti prema bližnjima). Dužnost u tom smislu podrazumijeva odgovornost za rezultate vlastitog djelovanja koji u pedagoškom kontekstu uvijek imaju odgojnu funkciju. Iz Benthamova koncepta dužnosti implementiraju se potrebe razvoja vrline razboritosti i nenanošenja štete drugima. U pedagoškoj profesiji dominantna je dužnost dobročinstva jer se odgojno djelovanje oslanja na pomoć odgajanicima u njihovu razvoju i sazrijevanju.

Radom se ističe veća potreba moralnog prosuđivanja u pedagoškom radu odgojitelja, kao i potreba njegovanja moralnih principa u odgojno-obrazovnoj kulturi škole koji su prijeko potrebni za uspješno ostvarivanje odgojno-obrazovnih ishoda. U tom smislu pedagoška deontologija podrazumijeva svijest o moralnim odgojnim postupcima odgojitelja i svih sudionika odgojnog procesa da bi se iz odgojiteljske dužnosti omogućio razvoj cjelovite, intelektualne, emocionalne i društveno-socijalno prihvatljive osobnosti učenika i štitio ih od negativnih i nepovoljnih utjecaja. 


\section{Mirko Lukaš* - Dean Cikovac*** \\ The Idea of Pedagogical Deontology Based on the Concepts of Duty \\ Summary}

The paper considers the possibility of establishing pedagogical deontology by considering three different philosophical concepts through which the ethical discourse of educational activity emphasizes the enduring need for moral educational action. This point of view indicates the strong need to update, nurture and develop the moral awareness of educators, which in the educational process is mediated to the student as a moral knowledge and experience. The deontological approach in the pedagogical activity includes the professional duties of the educator in relations to the student, other factors of the educational activity and towards the entire profession. The paper presents three different philosophical concepts of the idea of duty presented in the works of Marcus Tullius Cicero, Immanuel Kant and Jeremy Bentham. By analysing the author's observations and determinants of the idea of duty, guidelines for a modern approach to desirable moral educational action can be determined. The paper views the idea of duty as an obligation, responsibility and awareness of educational workers whose actions and statements affect the overall development of the personality of students. Therefore, the educational process, in addition to development, must necessarily act on the protection of students from possible harmful influences that appear every day as morally questionable and educationally unacceptable.

Key words: deontology, duty, educator, morality, profession, upbringing.

(na engl. prev. Dean Cikovac)

\footnotetext{
* Mirko Lukaš, PhD, Assoc. Prof., Faculty of Humanities and Social Sciences in Osijek; Address: Lorenza Jägera 9, HR-31000 Osijek, Croatia; E-mail: mirkolukas64@gmail.com.

**Dean Cikovac, Mag. Educ. Phil. et Mag. Paed., Gimnazija Gaudeamus; Address: Školska ul. 6, HR-31000 Osijek, Croatia; E-mail: dcikovac@ffos.hr.
} 